\author{
Mirosław Mielczarek ${ }^{1}$ (iD http:/orcid. org/0000-0001-9096-0715 \\ Dolnośląska Szkoła Wyższa
}

\title{
SPORT JAKO METODA INSTYTUCJONALNEJ RESOCJALIZACJI NIEDOSTOSOWANYCH SPOŁECZNIE DZIEWCZĄT
}

\section{Sports as a Method of Institutional Resocialization of Socially Adapted Girls}

Summary: The purpose of the considerations taken in the article is to show sport as a method of social rehabilitation of underage girls in an institutional environment. This goal corresponds to the problem of research - or contained in the question of completeness: whether, and if so, to what extent and how can sport be a desirable method of educational work in the process of institutional resocialization of socially maladjusted girls? 71 female minors in a youth educational center took part in the study. The research was carried out using the diagnostic survey method, taking into account the survey technique and its proprietary questionnaire acting as a research tool. Based on the research, the hypothesis was adopted that in the process of institutional resocialization of socially maladapted girls, sport is a desirable method of educational work, because it enjoys great interest, enables the development of sport passions, helps to spend time pleasantly, and reduces stress. In addition, the facilities of the youth educational center for the organization of sports activities and the competences of the teaching staff in the opinion of socially maladjusted girls are sufficient.

Keywords: sport, juvenile resocialization, resocialization methodology, socially maladjusted youth, difficult youth

1 Mgr Mirosław Mielczarek, doktorant Dolnośląskiej Szkoły Wyższej we Wrocławiu, Wydział Studiów Stosowanych, ul. Strzegomska 55, 53-611 Wrocław; e-mail: mirek91.m@gmail.com. 


\section{Wprowadzenie}

Zapewne istnieje szerokie grono osób, które ma pozytywne doświadczenia związane $\mathrm{z}$ oddziaływaniem aktywności fizycznej na własne samopoczucie i zdrowie. Najczęściej już od najmłodszych lat ludzie mają kontakt ze sportem, sami od dziecka starają się czynnie uczestniczyć w różnych dyscyplinach sportowych lub śledzą wydarzenia sportowe $\mathrm{w}$ mass mediach. Zdarza się, że rodzice tuż po narodzinach swojego dziecka widzą w nim sławnego piłkarza, biegacza czy innego sportowca. Już wtedy bardzo często starają się organizować zajęcia i zabawy tak, by ich potomek mógł nie tylko rozwijać swoją sprawność fizyczną, ale też przez wysiłek sportowy kształtować charakter i osobowość. W okresie dojrzewania młodzież z reguły sama zaczyna decydować o tym, co ją interesuje, dlatego samodzielnie wybiera dyscypliny sportowe i przejawia określone w tym celu zaangażowanie.

Sport jest metodą, $\mathrm{z}$ której chętnie w procesie wychowawczym korzystają nie tylko rodzice. Jest to jedna $\mathrm{z}$ bardziej znanych oraz popularnych metod stosowanych $\mathrm{w}$ procesie resocjalizacji. W jednostkach penitencjarnych, w których przebywają osadzeni, i w placówkach resocjalizacyjnych dla nieletnich sport jest nieodłącznym elementem codziennego rytmu dnia. Jego walory wychowawcze mają odzwierciedlenie w licznych projektach badawczych, które z reguły dotyczą roli sportu w procesie resocjalizacji chłopców. W mniejszym zaś stopniu badania w tym obszarze były prowadzone w placówkach przeznaczonych dla dziewcząt.

\section{Sport jako metoda resocjalizacji nieletnich}

Sport od zarania dziejów jest ważnym czynnikiem życia społecznego i kulturowego. Już w starożytności grecki filozof Platon uznał ćwiczenia fizyczne za „starszą siostrzycę wychowania duchowego"'2. Dowodem na to były organizowane igrzyska olimpijskie, gdzie można było publicznie prezentować swoje umiejętności w danej dyscyplinie sportowej. Osoby biorące udział w zawodach dla wielu były ucieleśnieniem doskonałości, a ich ciała służyły jako wzór ludzkiego piękna. Aktywność fizyczna była utożsamiana ze zdrowiem, pożytecznym spędzaniem czasu wolnego, ale przede wszystkim $\mathrm{z}$ nieodłącznym elementem wychowania jednostki. Walory sportu zostały dostrzeżone także w pracy resocjalizacyjnej. Dobrze zorganizowane zajęcia wychowania fizycznego rozładowują napięcie, redukują stres, poczucie lęku, wzmacniają mechanizmy kontrolne, uczą współpracy, poprawiają oraz utrzymują ogólny dobrostan zdrowia psychicznego i fizycznego. Profilaktyczne i terapeutyczne pozytywy sportu są związane z oddziaływaniem

2 Monika Jagielska, Sport i rekreacja w procesie resocjalizacji nieletnich, http://www.mow.powiat.koszalin.pl/przyklady/publikacje/MJ.pdf (dostęp: 8.02.2020). 
na deficyty behawioralne, takie jak wiednich wartości, niedostatek uspołecznienia, a także niedocenianie zdrowego stylu życia.

Jedni z prekursorów polskiej resocjalizacji, Czesław Czapów i Stanisław Jedlewski, włączyli sport oraz rekreację fizyczną do kulturotechnicznych metod oddziaływań resocjalizacyjnych, obok nauczania i pracy. ${ }^{4}$ W ich opinii poprzez tego typu zajęcia możliwe jest kształtowanie kluczowych cech osobowości, takich jak: opanowanie, wytrwałość, samodyscyplina, współdziałanie w grupie, dążenie do zamierzonego celu. Rolę sportu dostrzec można również w metodyce resocjalizacji Stanisława Górskiego ${ }^{5}$. Sport, podobnie jak u Czapowa i Jedlewskiego, został tam usytuowany w grupie metod kulturowych, gdzie znalazły się także nauka, praca, ale też wzory kulturowe. Sport i rekreacja, zdaniem Górskiego, odgrywają szczególną rolę w procesie resocjalizacji w przypadku dzieci i młodzieży niedostosowanej społecznie, ponieważ stanowią alternatywę dla działań wychowawczych. Związana jest ona przede wszystkim $\mathrm{z}$ aktywnym zagospodarowaniem czasu wolnego wychowanków po wypełnieniu wszystkich pozostałych obowiązków (szkolnego i innych). Ta metoda może być realizowana za pomocą gier zespołowych, zajęć rekreacyjnych, biwaków, rajdów, gier komputerowych i dyskotek. Ważne jest natomiast, by przestrzegać dobrowolności uczestnictwa w takich zajęciach. Gdy są one poprawnie zorganizowane, wpływają na rozładowanie napięcia, stresu, lęku, uczą poprawnej rywalizacji oraz kształtują interakcję społeczną. Sport to metoda, która - obok teatru resocjalizacyjnego, dramy, psychodramy, socjodramy, plastyki i muzyki - znalazła się również w koncepcji twórczej resocjalizacji Marka Konopczyńskiego ${ }^{6}$. To forma, która zakłada kreowanie określonych wzorców i kompetencji osobowych młodzieży przez wpływanie na jej tożsamość za pomocą sportu. Młodzież niedostosowana społecznie ma wówczas możliwość pełnienia odmiennych funkcji społecznych od dotychczas przejawianych. Sport korzystnie wpływa na rozwój intelektualny, psychiczny, społeczny, estetyczny i zdrowotno-fizyczny. Aktywność fizyczna jest tym czynnikiem, który daje młodzieży wzmocnienie, powodujące wiarę we własne możliwości, uczy zdrowej rywalizacji, współpracy, ładu i dyscypliny.

3 Krzysztof Sas-Nowosielski, „Wychowanie przez sport - między nadzieją a zwątpieniem (II)”, Sport Wyczynowy 7-8 (2004), 64-79.

4 Zob. Czesław Czapów, Stanisław Jedlewski, Pedagogika resocjalizacyjna (Warszawa: PWN, 1971).

5 Zob. Stanisław Górski, Metodyka resocjalizacji (Warszawa: Instytut Wydawniczy Związków Zawodowych, 1985).

6 Marek Konopczyński, Metody twórczej resocjalizacji (Warszawa: PWN, 2008). 


\section{Materiał i metody}

Badania zrealizowano w maju 2019 roku na terenie Młodzieżowego Ośrodka Wychowawczego (MOW) im. św. Siostry Faustyny w Krakowie, do którego kierowane są dziewczęta niedostosowane społecznie, w normie intelektualnej, w wieku od 13 do 18 lat, wobec których sąd rodzinny zastosował środek wychowawczy $\mathrm{w}$ postaci umieszczenia $\mathrm{w}$ takim ośrodku${ }^{7}$. Wybrana placówka ma status niepubliczny i jest prowadzona przez Zgromadzenie Sióstr Matki Bożej Miłosierdzia. Wychowanki na terenie ośrodka mają do dyspozycji salę gimnastyczną, siłownie, zewnętrzne boisko sportowe, salę teatralną, kaplicę do modlitwy, oddzielne świetlice dla każdej z grup oraz czteroosobowe pokoje mieszkalne. Ośrodek oferuje wychowankom wiele możliwości rozwijania zainteresowań, w tym sportowych. Działa w nim szkolny klub sportowy, koło zainteresowań turystycznych, teatralnych i muzycznych. Prowadzone są zajęcia $z$ fitnessu, zumby oraz wiele innych form aktywnego spędzania czasu wolnego. Liczebność grup wychowawczych nie przekracza dwunastu wychowanek, zwanych na mocy ustawy nieletnimi ${ }^{8}$.

Przedmiotem podjętych badań uczyniono sport jako metodę pracy wychowawczej $\mathrm{w}$ instytucjonalnym procesie resocjalizacji niedostosowanych społecznie dziewcząt. Ich celem było ukazanie sportu jako metody resocjalizacji nieletnich dziewcząt $w$ środowisku instytucjonalnym. Cel ten korespondował z problemem badawczym zawartym w pytaniu dopełnienia: czy - a jeżeli tak, to w jakim stopniu i w jaki sposób - sport może stanowić pożądaną metodę pracy wychowawczej $\mathrm{w}$ procesie instytucjonalnej resocjalizacji niedostosowanych społecznie dziewcząt? $?^{9}$ Tak sformułowanemu pytaniu nadano hipotezę zakładającą, że w procesie instytucjonalnej resocjalizacji niedostosowanych społecznie dziewcząt sport jest pożądaną metodą pracy wychowawczej, ponieważ cieszy się dużym zainteresowaniem, umożliwia rozwijanie pasji sportowych, pomaga przyjemnie spędzać czas, redukuje stres. Ponadto zaplecze MOW do organizacji zajęć sportowych i kompetencje kadry pedagogicznej w opinii niedostosowanych społecznie dziewcząt są wystarczające.

$\mathrm{W}$ prezentowanych badaniach wyznaczono zmienne, takie jak: zmienna niezależna $\left(\mathrm{Z}_{\mathrm{N}}\right)$ : wiek badanych; zmienna zależna $\left(\mathrm{Z}_{\mathrm{Z}}\right)$ : aktywność sportowa. Następnie wyznaczono wskaźniki (W) dla każdej ze zmiennych dokonując ich operacjonalizacji: $\mathrm{WZ}_{\mathrm{N}}$ - przedziały wiekowe (13-15 lat, 16-18 lat, 19-21 lat); $\mathrm{WZ}_{\mathrm{Z}}$ - odpowiedzi na pytania zawarte $\mathrm{w}$ kwestionariuszu ankiety.

7 Zob. Ustawa z dnia 26 października 1982 r. o postępowaniu w sprawach nieletnich, Dz.U. 1982, nr 35, poz. 228 ze zm., art. 6 , pkt 9.

8 Tamże, art. $1, \S 1$.

9 Problem badawczy składa się z trzech partykuł: „,czy”, „w jakim stopniu”, „w jaki sposób”, ponieważ zastosowanie tylko partykuły „w jakim stopniu” lub „w jaki sposób”, z pominięciem „czy”, od razu sugerowałoby odpowiedź „tak”. Tym samym z metodologicznego punktu widzenia nie jest wskazane, by pytanie sugerowało odpowiedź - stąd taki zabieg. 
Badania zrealizowano przy pomocy metody sondażu diagnostycznego ${ }^{10}$ z uwzględnieniem techniki ankiety. Narzędzie badawcze stanowił samodzielnie skonstruowany kwestionariusz ankiety składający się z instruktarzu, metryczki (wiek, rodzaj szkoły) oraz 13 pytań. Badania usytuowano w metodologii ilościowej utożsamianej z paradygmatem pozytywistycznym. Łącznie w przedsięwzięciu wzięły udział wszystkie obecne w chwili prowadzenia badań dziewczęta, których było 75 . W toku analiz okazało się, że $4 \mathrm{z}$ nich niepoprawnie wypełniły kwestionariusz ankiety. $\mathrm{W}$ wyniku takiego następstwa grupa badawcza liczyła 71 osób. W szystkie nieletnie, które uczestniczyły w badaniach, brały udział w zajęciach sportowych prowadzonych na terenie ośrodka. Liczebność uczestników badań nie przekraczała 100 osób, dlatego w analizach zrezygnowano $\mathrm{z}$ danych procentowych. Ze względu na to, że Autora interesowały różnice wewnątrzgrupowe, a nie międzygrupowe, zrezygnowano z prezentacji procentowej. Prezentacja jedynie częstości odpowiedzi przy tego typu porównaniach jest wystarczająca.

\section{Wyniki}

Od kadry pedagogicznej ośrodka otrzymano informacje, że nieletnie biorące udział w badaniach to młodzież niedostosowana społecznie wywodząca się z rodzin niewydolnych wychowawczo ze skumulowanymi czynnikami patogennymi, gdzie występowało ograniczenie lub pozbawienie władzy rodzicielskiej. Najczęstszym powodem umieszczenia dziewcząt w MOW była nadmierna absencja szkolna, współwystępująca w niektórych przypadkach z zażywaniem środków psychoaktywnych lub ich posiadaniem, kradzieżami, bójkami i pobiciami. Najwięcej osób badanych uczęszczało do szkoły podstawowej $(n=32)$, następnie do szkoły branżowej $(n=26)$, a najmniej do liceum $(n=13)$. Grupa badawcza mieściła się $\mathrm{w}$ trzech przedziałach wiekowych: 13-15 lat $(\mathrm{n}=8)$; 16-18 lat $(\mathrm{n}=56)$; 19-21 lat $(\mathrm{n}=7) . \mathrm{Z}$ zebranych danych wynika, że najliczniejszą grupę stanowiły dziewczęta w wieku od 16. do 21. roku życia. Przedziały wiekowe zostały wykorzystane jako zmienna pośrednicząca $\left(\mathrm{Z}_{\mathrm{P}}\right)$ przy tabelarycznej prezentacji wyników. Pierwsze zagadnienie, jakie poruszono podczas badań, dotyczyło zainteresowań dyscyplinami sportowymi. Jak się okazało w toku prowadzenia badań, wszystkie dyscypliny, które uwzględniał kwestionariusz ankiety, były realizowane na terenie MOW. Zebrane wyniki zaprezentowano w tabeli 1.

10 Zob. Tadeusz Pilch, Teresa Bauman, Zasady badań pedagogicznych. Strategie ilościowe i jakościowe (Warszawa: Wydawnictwo Akademickie „Żak”, 2001). 
Tabela 1. Zainteresowanie dyscyplinami sportowymi w grupie nieletnich dziewcząt z MOW

\begin{tabular}{|l|c|c|c|c|}
\hline Dyscypliny sportowe & $\mathbf{1 3 - 1 5}$ lat & $\mathbf{1 6 - 1 8 ~ l a t ~}$ & $\mathbf{1 9 - 2 1}$ lat & Ogółem \\
\hline Siatkówka & 6 & 42 & 5 & 53 \\
\hline Lekkoatletyka & 1 & 10 & 1 & 12 \\
\hline Gimnastyka & 2 & 9 & 1 & 12 \\
\hline Tenis stołowy & 1 & 6 & 0 & 7 \\
\hline Taniec & 5 & 37 & 5 & 47 \\
\hline Koszykówka & 0 & 16 & 1 & 17 \\
\hline Inna (jaka?) & 0 & 0 & 0 & 0 \\
\hline
\end{tabular}

* Pytanie wielokrotnego wyboru, dlatego zamieszczone dane nie sumują się do 71 .

Źródło: badania własne.

Z danych w tabeli 1 wynika, że w przedziale wiekowym 13-15 lat największą popularnością cieszyła się siatkówka - 6 wskazań, następnie taniec - 5 wskazań. Kolejne miejsce osiągnęła gimnastyka - 2 wskazania, 1 wskazanie otrzymała lekkoatletyka, natomiast koszykówka i tenis stołowy żadnego. W najliczniejszym przedziale wiekowym, 16-18 lat, na pierwszym miejscu z wynikiem 42 wskazań również uplasowała się siatkówka, później taniec - 37 wskazań, na trzeciej pozycji znalazła się koszykówka - 16 wskazań. Najczęściej wybieraną dyscypliną była lekkoatletyka - 10 wskazań, a tuż za nią gimnastyka - 9 wskazań. Najmniejsze zainteresowanie $\mathrm{w}$ tym przedziale wiekowym osiągnął tenis stołowy - 6 wskazań. W najstarszym przedziale wiekowym, 19-21 lat, największym zainteresowaniem cieszyły się siatkówka oraz taniec, obie dyscypliny otrzymały po 5 wskazań, z kolei pozostałe tylko po 1 wskazaniu. Nikt z grupy badawczej nie wskazał innej dyscypliny sportowej poza tymi, które uwzględniał kwestionariusz. Podsumowując, należy wskazać, że w grupie niedostosowanych społecznie dziewcząt największym zainteresowaniem wśród dyscyplin sportowych cieszyła się siatkówka, a najmniejszym tenis stołowy.

Tabela 2. Powody aktywności fizycznej nieletnich dziewcząt z MOW

\begin{tabular}{|l|c|c|c|c|}
\hline Powody aktywności fizycznej & $\mathbf{1 3 - 1 5}$ lat & $\mathbf{1 6 - 1 8}$ lat & $\mathbf{1 9 - 2 1}$ lat & Ogółem \\
\hline Przyjemne spędzanie czasu & 3 & 25 & 3 & 31 \\
\hline Bycie wysportowanym i sprawnym & 3 & 18 & 3 & 24 \\
\hline Poprawa sylwetki & 4 & 28 & 5 & 37 \\
\hline Przedmiot obowiązkowy & 1 & 4 & 0 & 5 \\
\hline Inne (jakie?) & 3 & 2 & 1 & 6 \\
\hline
\end{tabular}

* Pytanie wielokrotnego wyboru, dlatego zamieszczone dane nie sumują się do 71 .

Źródło: badania własne. 
W tabeli 2 zaprezentowano wyniki ukazujące powody uczestnictwa dziewcząt w zajęciach sportowych prowadzonych na terenie ośrodka. Dane pokazują, że w przedziale wiekowym 13-15 lat nieletnie najczęściej ćwiczyły z powodu chęci poprawy sylwetki - 4 wskazania, następnie zarówno chęć przyjemnego spędzania czasu, jak i bycia wysportowanym i sprawnym uzyskały po 3 wskazania. Tylko jedna osoba udzieliła odpowiedzi, że jest to przedmiot obowiązkowy i musi w nim uczestniczyć. W najliczniejszym przedziale wiekowym, 16-18 lat, największą liczbę wskazań otrzymał powód chęci poprawy sylwetki - 28 wskazań, nieco mniej, bo 25 - chęć przyjemnego spędzania czasu. Na trzeciej pozycji z liczbą 18 wskazań uplasowała się możliwość bycia wysportowanym i sprawnym. Tylko 4 odpowiedzi dotyczą aktywności fizycznej jako przedmiotu obowiązkowego. W grupie wiekowej 19-21 lat najwięcej osób udzieliło odpowiedzi dotyczącej poprawienia sylwetki - 5 wskazań, po 3 wskazania otrzymała chęć przyjemnego spędzania czasu oraz bycia wysportowanym i sprawnym, natomiast nikt nie uznał aktywności fizycznej za przedmiot obowiązkowy. Wśród innych powodów sporadycznie powtarzały się odpowiedzi takie jak: „bo to lubię”, „chcę schudnąć”. Jedna osoba wpisała jako powód „chęć rozładowania stresu”. Badania pokazały, że nieletnie z MOW uprawiały sport głównie dla chęci poprawy własnej sylwetki oraz przyjemnego spędzenia czasu wolnego. W mniejszym stopniu robiły to $\mathrm{z}$ uwagi na traktowanie zajęć sportowych jako obowiązkowego przedmiotu.

Tabela 3. Rola, jaką odgrywa sport w życiu nieletnich dziewcząt z MOW

\begin{tabular}{|l|c|c|c|c|}
\hline \multicolumn{1}{|c|}{ Rola sportu w życiu } & $\mathbf{1 3 - 1 5}$ lat & $\mathbf{1 6 - 1 8 ~ l a t ~}$ & $\mathbf{1 9 - 2 1}$ lat & Ogółem \\
\hline Utrzymywanie dobrego zdrowia & 4 & 24 & 7 & 35 \\
\hline Dawanie przyjemności & 7 & 33 & 4 & 44 \\
\hline Sposób na wolny czas & 3 & 33 & 2 & 38 \\
\hline Zabicie nudy & 0 & 4 & 0 & 4 \\
\hline Strata czasu & 0 & 4 & 0 & 4 \\
\hline Styl życia & 5 & 15 & 2 & 22 \\
\hline
\end{tabular}

* Pytanie wielokrotnego wyboru, dlatego zamieszczone dane nie sumują się do 71 .

Źródło: badania własne.

Wyniki $\mathrm{z}$ tabeli 3 pokazują, że ankietowane $\mathrm{w}$ przedziale wiekowym 13-15 lat najczęściej udzielały odpowiedzi, iż rolą sportu jest dawanie przyjemności - 7 wskazań, na drugim miejscu znalazł się styl życia z liczbą 5 odpowiedzi. Tylko 4 osoby uznały, że sport wiąże się z utrzymaniem dobrego zdrowia, a 3 wskazały na niego jako sposób spędzania wolnego czasu. Nikt nie wytypował odpowiedzi, że jest to strata czasu oraz sposób na zabicie nudy. W grupie osób mających 16-18 lat na pierwszym miejscu z liczbą 33 wskazań znalazła się „przyjemnośc” 
wraz ze sposobem spędzania wolnego czasu. Wysoki wynik uzyskało także zdrowie, ponieważ aż 24 osoby udzieliły takiej odpowiedzi. Dla 15 dziewcząt rola sportu była powiązana ze stylem życia. Odpowiedzi „strata czasu” oraz „zabicie nudy” uzyskały po 4 wskazania. Najstarsze osoby najwięcej odpowiedzi - 7 - przyznały zdrowiu, na drugim miejscu znalazła się przyjemność - 4 wskazania. Po 2 typy otrzymał „styl życia” oraz „sposób na wolny czas”. Nikt nie stwierdził, że sport jest „stratą czasu” oraz formą na „zabicie nudy”. Z badań wynika, że dla niedostosowanych społecznie dziewcząt rola sportu w życiu człowieka wiązała się głównie z przyjemnością, sposobem na spędzenie wolnego czasu oraz utrzymaniem dobrego stanu zdrowia. W nielicznych przypadkach rola sportu była utożsamiana ze stratą czasu i sposobem na nudę.

Tabela 4. Częstotliwość uprawiania sportu w grupie nieletnich dziewcząt z MOW

\begin{tabular}{|l|c|c|c|c|}
\hline Częstotliwość uprawiania sportu & $\mathbf{1 3 - 1 5}$ lat & $\mathbf{1 6 - 1 8}$ lat & $\mathbf{1 9 - 2 1}$ lat & Ogółem \\
\hline 1 raz w tygodniu & 0 & 7 & 1 & 8 \\
\hline 2 razy w tygodniu & 1 & 11 & 1 & 13 \\
\hline 3 razy w tygodniu & 2 & 21 & 5 & 28 \\
\hline 4 razy w tygodniu i więcej & 5 & 17 & 0 & 22 \\
\hline Ogółem & 8 & 56 & 7 & 71 \\
\hline
\end{tabular}

Źródło: badania własne.

Dziewczęta z przedziału wiekowego 13-15 lat najczęściej udzielały odpowiedzi, iż ćwiczą częściej niż 4 razy w tygodniu, takiej odpowiedzi udzieliło 5 osób. Kolejne 2 wskazania uzyskał wynik 3 razy w tygodniu, a tylko jedna osoba zaznaczyła odpowiedź 2 razy w tygodniu. Nikt nie udzielił odpowiedzi, że ćwiczy raz w tygodniu. W grupie wiekowej 16-18 lat największą popularnością cieszyła się odpowiedź 3 razy w tygodniu - 21 wskazań, później 4 razy w tygodniu lub więcej - 17 wskazań. Na trzecim miejscu znalazła się odpowiedź 2 razy w tygodniu 11 wskazań. Najmniej osób udzieliło odpowiedzi raz w tygodniu - 7 wskazań. W najstarszej grupie wiekowej najwięcej odpowiedzi przypadło na 3 razy w tygodniu 5 wskazań. Po 1 wskazaniu otrzymały odpowiedzi 1 oraz 2 razy w tygodniu. Nikt nie udzielił odpowiedzi 4 razy w tygodniu lub więcej. Aktywność fizyczna wśród niedostosowanych społecznie dziewczyn cieszyła się sporym zainteresowaniem, systematycznością oraz nie ograniczała się tylko i wyłącznie do obowiązkowych zajęć wychowania fizycznego. 
Tabela 5. Wyposażenie MOW pod kątem zajęć sportowych

\begin{tabular}{|l|c|c|c|c|}
\hline $\begin{array}{c}\text { Wyposażenie ośrodka pod } \\
\text { kątem realizacji zajęć sportowych }\end{array}$ & 13-15 lat & 16-18 lat & 19-21 lat & Ogółem \\
\hline Zdecydowanie odpowiednie & 4 & 34 & 2 & 40 \\
\hline Raczej odpowiednie & 4 & 21 & 5 & 30 \\
\hline Raczej nieodpowiednie & 0 & 1 & 0 & 1 \\
\hline Zdecydowanie nieodpowiednie & 0 & 0 & 0 & 0 \\
\hline Ogółem & 8 & 56 & 7 & 71 \\
\hline
\end{tabular}

Źródło: badania własne.

W przedziale wiekowym 13-15 lat pojawiły się 4 odpowiedzi wskazujące na to, że wybrany MOW w opinii dziewcząt dysponował zdecydowanie odpowiednim wyposażeniem pod kątem realizacji zajęć sportowych. Tyle samo nieletnich stwierdziło, że raczej odpowiednim. Nikt nie uznał, że raczej nieodpowiednim i zdecydowanie nieodpowiednim. W grupie wiekowej 16-18 lat najczęściej powtarzała się odpowiedź „zdecydowanie odpowiednie” - 34 wskazania. Następnych 21 wskazań uzyskała odpowiedź „raczej odpowiednie”. Zaledwie jedna osoba uznała, że wyposażenie ośrodka w badanym kontekście było „raczej nieodpowiednie”. Nikt nie udzielił odpowiedzi „zdecydowanie nieodpowiednie”. Dziewczęta w wieku 19-21 lat udzieliły 5 wskazań dla odpowiedzi „raczej odpowiednie” i tylko 2 dla „zdecydowanie odpowiednie”. Nie pojawiły się odpowiedzi „raczej nieodpowiednie” i „zdecydowanie nieodpowiednie”. W opinii dziewcząt ich MOW dysponował zdecydowanie bardzo dobrym wyposażeniem sportowym, które pozwalało i pomagało rozwijać im pasje sportowe. Tylko jedna nieletnia uważała inaczej.

Tabela 6. Informacje udzielane przez nauczyciela/trenera podczas zajęć sportowych na temat regulaminowych zasad gry

\begin{tabular}{|l|c|c|c|c|}
\hline $\begin{array}{c}\text { Udzielanie informacji przez } \\
\text { nauczyciela/trenera na temat } \\
\text { regulaminowych zasad gry }\end{array}$ & $\mathbf{1 3 - 1 5}$ lat & $\mathbf{1 6 - 1 8}$ lat & $\mathbf{1 9 - 2 1}$ lat & Ogółem \\
\hline Zdecydowanie tak & 3 & 24 & 3 & 30 \\
\hline Raczej tak & 3 & 26 & 4 & 33 \\
\hline Raczej nie & 2 & 6 & 0 & 8 \\
\hline Zdecydowanie nie & 0 & 0 & 0 & 0 \\
\hline Ogółem & 8 & 56 & 7 & 71 \\
\hline
\end{tabular}

Źródło: badania własne. 
Tabela 6 przedstawia wyniki dotyczące udzielania informacji przez nauczyciela/ trenera na temat regulaminowych zasad gry podczas zajęć sportowych. W grupie wiekowej 13-15 lat po 3 wskazania uzyskały odpowiedzi „zdecydowanie tak” oraz „raczej tak”. Tylko 2 osoby udzieliły odpowiedziały „raczej nie”. Nikt nie zaznaczył odpowiedzi „zdecydowanie nie”. W najliczniejszym przedziale wiekowym, 16-18 lat, najczęściej powtarzała się odpowiedź „raczej tak” - 26 wskazań. Kolejne 24 wskazania przypadły odpowiedzi „zdecydowanie tak”, a następnych 6 dla „raczej nie”. Ani jednego wskazania nie było dla odpowiedzi „zdecydowanie nie”. W przedziale wiekowym 19-21 lat padły 4 wskazania dla odpowiedzi „raczej tak” i 3 dla „zdecydowanie tak”. Nikt nie udzielił odpowiedzi „raczej nie” oraz „zdecydowanie nie". Dane wskazują, że dziewczęta uzyskiwały od kadry pedagogicznej MOW odpowiednie informacje na temat zasad oraz regulaminów gier prowadzonych $\mathrm{w}$ ramach zajęć sportowych.

Tabela 7. Możliwości rozwijania pasji sportowych na terenie MOW

\begin{tabular}{|l|c|c|c|c|}
\hline $\begin{array}{c}\text { Możliwość rozwijania } \\
\text { pasji sportowych }\end{array}$ & $\mathbf{1 3 - 1 5}$ lat & $\mathbf{1 6 - 1 8}$ lat & $\mathbf{1 9 - 2 1}$ lat & Ogółem \\
\hline Zdecydowanie tak & 5 & 28 & 2 & 35 \\
\hline Raczej tak & 2 & 25 & 4 & 31 \\
\hline Raczej nie & 1 & 3 & 1 & 5 \\
\hline Zdecydowanie nie & 0 & 0 & 0 & 0 \\
\hline Ogółem & 8 & 56 & 7 & 71 \\
\hline
\end{tabular}

Źródło: badania własne.

W przedziale wiekowym 13-15 lat większość dziewcząt zdecydowanie uważała, że ośrodek, w którym przebywają, pozwala im rozwijać pasje sportowe 5 wskazań. Raczej za tym stwierdzeniem opowiedziały się 2 wychowanki. Jedna osoba stwierdziła, że raczej tak nie jest. W grupie 16-18 lat najczęściej powtarzała się odpowiedź „Zdecydowanie tak” - 28 wskazań. Z kolei odpowiedź „raczej tak” miała 25 wskazań. Zaledwie tylko 3 osoby udzieliły odpowiedzi „raczej nie”. W najstarszej grupie najwięcej wskazań przypadło odpowiedzi „raczej tak” 4 wskazania. Za stwierdzeniem „zdecydowanie tak” opowiedziały się 2 dziewczyny, a za „raczej nie” tylko 1 . Odpowiedź „zdecydowanie nie” we wszystkich przedziałach wiekowych nie otrzymała ani jednego wskazania. Większość dziewcząt uznała, że MOW, w jakim obecnie przebywają, daje im możliwości rozwijania własnych pasji sportowych. 
Tabela 8. Sposoby rozwijania pasji sportowych na terenie MOW

\begin{tabular}{|l|c|c|c|c|}
\hline Sposoby rozwijania pasji sportowych & $\mathbf{1 3 - 1 5}$ lat & $\mathbf{1 6 - 1 8}$ lat & $\mathbf{1 9 - 2 1}$ lat & Ogółem \\
\hline $\begin{array}{l}\text { Czytanie książek i czasopism } \\
\text { sportowych }\end{array}$ & 1 & 13 & 2 & 16 \\
\hline $\begin{array}{l}\text { Śledzenie wydarzeń i wiadomości } \\
\text { sportowych }\end{array}$ & 5 & 14 & 2 & 21 \\
\hline Treningi sportowe & 6 & 44 & 3 & 53 \\
\hline Wyjazdy na wydarzenia sportowe & 1 & 20 & 3 & 24 \\
\hline $\begin{array}{l}\text { Czynny udział w zawodach } \\
\text { sportowych }\end{array}$ & 0 & 13 & 2 & 15 \\
\hline
\end{tabular}

* Pytanie wielokrotnego wyboru, dlatego zamieszczone dane nie sumują się do 71 .

Źródło: badania własne.

W tabeli 8 przedstawiono sposoby rozwijania pasji sportowych w MOW przez nieletnie. $Z$ danych wynika, że w najmłodszej grupie wiekowej najczęstszym sposobem rozwijania pasji sportowych były treningi - 6 wskazań - oraz nieco mniej popularnym - śledzenie wydarzeń i wiadomości sportowych - 5 wskazań. Czytanie książek i czasopism sportowych oraz możliwość wyjazdów na wydarzenia sportowe otrzymały po 1 wskazaniu. Nikt nie udzielił odpowiedzi „czynny udział w zawodach sportowych". W przedziale wiekowym 16-18 lat najpopularniejszą odpowiedzią był również trening sportowy - 44 wskazania, następną - wyjazd na wydarzenia sportowe - 20 wskazań. Liczbę 14 wskazań uzyskała odpowiedź „oglądanie wydarzeń i wiadomości sportowych”. Po 13 wskazań miały zarówno czytanie książek i czasopism sportowych, jak i czynny udział w zawodach sportowych. W najstarszej grupie wiekowej po 3 wskazania przypadły odpowiedzi „treningi sportowe” oraz „wyjazdy na wydarzenia sportowe”, po 2 otrzymały pozostałe kategorie. Wybrany do badań MOW umożliwiał wychowankom rozwijanie pasji sportowych. Aby je realizować, nieletnie najczęściej decydowały się brać udział w treningach oraz wyjazdach na wydarzenia sportowe.

Tabela 9. Uczestnictwo w szkolnym klubie sportowym na terenie MOW

\begin{tabular}{|l|c|c|c|c|}
\hline \multicolumn{1}{|c|}{ Odpowiedzi } & $\mathbf{1 3 - 1 5}$ lat & $\mathbf{1 6 - 1 8 ~ l a t ~}$ & $\mathbf{1 9 - 2 1}$ lat & Ogółem \\
\hline Tak & 6 & 23 & 1 & 30 \\
\hline Nie & 2 & 33 & 6 & 41 \\
\hline Ogółem & 8 & 56 & 7 & 71 \\
\hline
\end{tabular}

Źródło: badania własne. 
Z przedziału wiekowego 13-15 lat 6 dziewcząt uczęszczało na zajęcia szkolnego klubu sportowego, a pozostałe 2 nie. W grupie 16-18 lat taką aktywność wykazywały 23 osoby, a jej brak 33. Spośród najstarszych wychowanek tylko 1 uczęszczała na zajęcia sportowe, a kolejnych 6 nie brało w nich udziału. Wyniki wskazują, że prawie połowa niedostosowanych społecznie dziewcząt uczestniczyła w zajęciach szkolnego klubu sportowego organizowanych na terenie MOW.

Tabela 10. Chęć zwiększenia liczby zajęć sportowych na terenie MOW

\begin{tabular}{|l|c|c|c|c|}
\hline \multicolumn{1}{|c|}{ Odpowiedzi } & $\mathbf{1 3 - 1 5}$ lat & $\mathbf{1 6 - 1 8 ~ l a t ~}$ & $\mathbf{1 9 - 2 1}$ lat & Ogółem \\
\hline Tak & 5 & 36 & 5 & 46 \\
\hline Obojętnie & 2 & 14 & 2 & 18 \\
\hline Nie & 1 & 6 & 0 & 7 \\
\hline Ogółem & 8 & 56 & 7 & 71 \\
\hline
\end{tabular}

Źródło: badania własne.

Za zwiększeniem liczby zajęć sportowych na terenie MOW opowiedziało się 5 dziewcząt $\mathrm{z}$ przedziału wiekowego 13-15 lat. Dla 2 wychowanek było to obojętne, a 1 była temu przeciwna. Z grupy 16-18 lat było aż 36 wskazań za zwiększeniem liczby takich godzin, 14 osób uznało, że jest im to obojętne, a 6 nieletnich wyraziło wobec tego swój sprzeciw. W najstarszej grupie 5 wskazań znalazło się po stronie zwiększenia wymiaru czasu zajęć sportowych, 2 osoby wyraziły obojętność. Nikt nie udzielił odpowiedzi świadczącej o braku potrzeby zwiększania wymiaru czasu zajęć sportowych. Z badań wynika, że spora większość dziewcząt była za zwiększeniem wymiaru czasu zajęć sportowych realizowanych na terenie MOW.

Tabela 11. Udział w zawodach sportowych

\begin{tabular}{|l|c|c|c|c|}
\hline \multicolumn{1}{|c|}{ Odpowiedzi } & 13-15 lat & 16-18 lat & 19-21 lat & Ogółem \\
\hline Tak, brałam udział & 3 & 36 & 4 & 43 \\
\hline Tak, zamierzam wziąć udział & 4 & 14 & 1 & 19 \\
\hline Nie brałam udziału & 3 & 8 & 2 & 13 \\
\hline Nie zamierzam brać udziału & 0 & 6 & 0 & 6 \\
\hline
\end{tabular}

* Pytanie wielokrotnego wyboru, dlatego zamieszczone dane nie sumują się do 71 .

Źródło: badania własne.

W przedziale wiekowym 13-15 lat najwięcej wskazań - 4 - uzyskała odpowiedź „tak, zamierzam wziąć udział” w zawodach sportowych. Kolejne 3 wskazania uzyskała odpowiedź mówiąca o tym, że respondentki brały udział 
w zawodach, ale również $3 \mathrm{w}$ nich nie uczestniczyły. Nikt z tej grupy nie udzielił odpowiedzi, że nie zamierza brać udziału w zawodach sportowych. W najliczniejszej grupie wiekowej, 16-18 lat, aż 36 osób brało udział w takich zawodach, 14 zamierza, a tylko 8 osób nie brało nigdy udziału. Pozostałych 6 badanych nie zamierza w ogóle wziąć udziału. W przedziale wiekowym 19-21 lat najwięcej wskazań - 4 - uzyskała odpowiedź „tak, brałam udział w zawodach”, 2 wskazania padły dla odpowiedzi „nie brałam udziału” oraz 1 dla „zamierzam wziąć udział w zawodach". Żadna respondentka nie udzieliła odpowiedzi świadczącej o tym, że nie zamierza brać udziału w zawodach sportowych. W badanym ośrodku zdecydowana większość dziewcząt brała udział w zawodach sportowych, a część nadal chciała w nich uczestniczyć.

Tabela 12. Redukcja stresu przez aktywność fizyczną prowadzoną w MOW

\begin{tabular}{|l|c|c|c|c|}
\hline $\begin{array}{c}\text { Możliwość rozwijania pasji } \\
\text { sportowych }\end{array}$ & 13-15 lat & 16-18 lat & 19-21 lat & Ogółem \\
\hline Zdecydowanie tak & 5 & 24 & 4 & 33 \\
\hline Raczej tak & 2 & 27 & 3 & 32 \\
\hline Raczej nie & 0 & 3 & 0 & 3 \\
\hline Zdecydowanie nie & 1 & 2 & 0 & 3 \\
\hline Ogółem & 8 & 56 & 7 & 71 \\
\hline
\end{tabular}

Źródło: badania własne.

W grupie wiekowej 13-15 lat nieletnie najczęściej typowały odpowiedź, iż aktywność fizyczna zdecydowanie pomaga obniżyć im poziom stresu - 5 wskazań. Kolejne 2 osoby zaznaczyły odpowiedź „raczej tak”. Jedna ankietowana zaznaczyła stwierdzenie „zdecydowanie nie”. W najliczniejszym przedziale wiekowym 27 osób udzieliło odpowiedzi „raczej tak”, a 24 - „zdecydowanie tak”. Pozostałe 3 respondentki wybrały odpowiedź „raczej nie” i tylko 2 - „zdecydowanie nie”. W najstarszej grupie wiekowej, 19-21 lat, wszystkim dziewczętom aktywność fizyczna pozwala pozbyć się stresu, ponieważ 4 nieletnie wybrały odpowiedź „zdecydowanie tak”, a 3 udzieliły wskazania „raczej tak”. Zebrany materiał pokazał, że zdecydowana większość grupy badawczej uważała, iż aktywność fizyczna pomaga zmniejszyć poziom stresu oraz zgromadzonego napięcia. 
Tabela 13. Typ ćwiczeń sportowych, poprzez który następuje redukcja poziomu stresu

\begin{tabular}{|l|c|c|c|c|}
\hline Rodzaj aktywności fizycznej & $\mathbf{1 3 - 1 5}$ lat & $\mathbf{1 6 - 1 8}$ lat & $\mathbf{1 9 - 2 1}$ lat & Ogółem \\
\hline Biegi & 3 & 31 & 5 & 39 \\
\hline Pompki & 1 & 7 & 1 & 9 \\
\hline Skłony, brzuszki & 3 & 16 & 1 & 20 \\
\hline Trening indywidualny & 4 & 19 & 1 & 24 \\
\hline
\end{tabular}

* Pytanie wielokrotnego wyboru, dlatego zamieszczone dane nie sumują się do 71 .

Źródło: badania własne.

W najmniejszym przedziale wiekowym najczęściej wybieranym typem aktywności sportowej, poprzez który u dziewcząt następowała redukcja poziomu stresu, był trening indywidualny - 4 wskazania - oraz biegi wraz ze skłonami (brzuszkami) - po 3 wskazania. U jednej nieletniej redukcja stresu następowała przez robienie pompek. W grupie 16-18 lat najpopularniejszą formą okazały się biegi - 31 wskazań, później trening indywidualny - 19 wskazań, skłony (brzuszki) - 16 wskazań, pompki - 7 wskazań. W najmniej licznej grupie największą liczbę odpowiedzi uzyskały biegi - 5 wskazań, a pozostałe aktywności fizyczne tylko po 1 wskazaniu. Z badań wynika, że dziewczętom w zwalczaniu stresu poprzez aktywność fizyczną najbardziej pomagało bieganie, a w najmniejszym stopniu robienie pompek.

\section{Dyskusja}

Z przeprowadzonych badań wynika, że zaangażowanie nieletnich w zajęcia sportowe jest duże. Do podobnych wniosków doszli Jadwiga Robacha i Małgorzata Kostrzyńska ${ }^{11}$, Elena Karpuszenko i Arkadiusz Marzec ${ }^{12}$ oraz Ewa Zimna-Walendzik i Franciszek Szatko ${ }^{13}$. Z badań Michała Tkaczyka i Małgorzaty Paczyńskiej-Jędryckiej wyłania się stwierdzenie, że wychowanie w duchu kultury fizycznej niesie za sobą cenne wartości wychowawcze, w tym niezbędne w procesie

${ }^{11}$ Jadwiga Robacha, Małgorzata Kostrzyńska, „Postawy młodzieży niedostosowanej społecznie wobec aktywności fizycznej”. W: Zapobieganie wykluczeniu z systemu edukacji dzieci i młodzieży nieprzystosowanej społecznie. Perspektywa pedagogiczna, red. Joanna Elżbieta Kowalska (Łódź: Wydawnictwo Uniwersytetu Łódzkiego, 2014), 201-217.

${ }^{12}$ Elena Karpuszenko, Arkadiusz Marzec, Sport w resocjalizacji nieletnich (Częstochowa: Akademia im. Jana Długosza, 2008).

${ }^{13}$ Ewa Zimna-Walendzik, Franciszek Szatko, „Udział sportu w modyfikacji stylu życia młodzieży resocjalizowanej”, Problemy Higieny i Epidemiologii 93 (1) (2012), 67-70. 
resocjalizacji ${ }^{14}$. W badaniach Roberta Pokleka okazało się, że skazani, którzy uprawiali gry zespołowe (piłkę nożną, siatkówkę, koszykówkę), przejawiali niższy wskaźnik syndromu agresji, a jednocześnie mieli najwyższy poziom kontroli swoich zachowań agresywnych. Podobnie było w przypadku tych osób, które trenowały tenis stołowy, badminton, gimnastykę i lekkoatletykę. Najwyższy zaś poziom nasilenia syndromu zachowań agresywnych spośród wszystkich badanych mieli ci, którzy uprawiali sporty siłowe (kulturystykę, podnoszenie ciężarów, wieloboje siłowe $)^{15}$. Może to sugerować niekorzystne oddziaływanie tych dyscyplin sportowych na przejawianą przez młodocianych agresywność. Z drugiej strony dyscypliny sportowe, które - jak wynika z przytoczonych badań sprzyjały niwelowaniu zachowań agresywnych, były uprawiane przez dziewczęta z MOW w Krakowie. Natomiast te sporty, które prawdopodobnie mogą wzmagać zachowania niepożądane, we wskazanym ośrodku nie były uprawiane przez żadną $\mathrm{z}$ nieletnich.

W większości badań można znaleźć wspólny mianownik, jakim jest pozytywne oddziaływanie sportu na proces wychowawczy. Takie przesłanki wyłaniają się między innymi z dociekań amerykańskich badaczy, którzy wykazali istotne korelacje pomiędzy ilością wydatku energetycznego oddawanego podczas ćwiczeń fizycznych w przeciągu tygodnia a takimi cechami osobowości jak: sumienność, neurotyczność, ekstrawersja. Korelacja okazała się pozytywna między ekstrawersją i sumiennością, natomiast ujemna w przypadku neurotyczności ${ }^{16}$. W zakresie cech „Wielkiej Piątki” najsilniejszym korelatem aktywności sportowej w większości okazywała się sumienność ${ }^{17}$. Z kolei w obszarze „Wielkiej Trójki” każdy z jej wymiarów ${ }^{18}$. Empirycznie potwierdzono, że osoby uprawiające regularnie sport odznaczają się wyższym poziomem sumienności i stabilności emocjonalnej. Sportowcy przejawiają również większą otwartość na doświadczenia oraz ekstrawersję niż osoby, które nie uprawiają żadnej dyscypliny sportowej ${ }^{19}$.

${ }^{14}$ Michał Tkaczyk, Małgorzata Paczyńska-Jędrycka, Pedagogika kultury fizycznej w pracy resocjalizacyjnej poznańskiego zakładu poprawczego, http://www.poznan.zp.gov.pl/wp-content/uploads/2018/05/Pedagogika-kultury-fizycznej.pdf (dostęp: 10.02.2020).

15 Robert Poklek, „Wpływ aktywności fizycznej na poziom agresji młodocianych przestępców”, Zeszyty Naukowe Wyższej Szkoły Pedagogiki i Administracji w Poznaniu 2 (2006), 234-243.

${ }_{16}$ Tom Bogg, Beniamin William Roberts, „Conscientiousness and Health-Related Behaviors: A Meta-Analysis of the Leading Behavioral Contributors to Morality", Psychological Bulletin 130 (2004), 887-919.

17 Ryan Rhodes, Neil Smith, „Personality Correlates of Phisical Activity: A Review and Meta-Analysis”, British Journal of Sports Medicine 40 (2006), 958-965; Patrick Gallagher, William Yancy, Jaap Denisen, Anja Kühnel, Corrine Voils, „Correlates of Daily Leisure-Time Physical Activity in a Community Sample: Narrow Personality Traits and Practical Barriers", Health Psychology 1 (6) (2012).

18 Hans Jürgen Eysenck, Don Karl Bean Nias, Dan Norman Cox, „Advances in Behaviour Research \& Therapy", Sport and Personality 4 (1982), 170-199.

19 Tanja Kajtna, Matej Tusak, Renata Barić, Stojan Burnik, „Personality in High-Risk Sports Athletes", Kinesiology 36 (1) (2004), 24-34. 
Badania wskazują, że takie dyscypliny sportowe jak na przykład piłka nożna mogą korelować $\mathrm{z}$ wyższym poziomem agresywności ${ }^{20}$. Tymczasem $\mathrm{w}$ wielu dyscyplinach sportowych zachowanie uczestników jest ukierunkowane na wyrządzenie krzywdy drugiej osobie lub zadanie cierpienia ${ }^{21}$. W niektórych też dyscyplinach zachowania aspołeczne są dość powszechne, a nawet wręcz pożądane przez publiczność.

Badania nad rolą sportu w resocjalizacji są głównie dostępne w publikacjach psychologicznych i pedagogicznych. Analizując je, właściwie trudno jest dostrzec negatywne oddziaływanie aktywności fizycznej na funkcjonowanie jednostki. Większość badaczy jest zgodna, że uprawianie sportu pomaga nie tylko racjonalnie wypełniać czas wolny, utrzymywać w dobrej formie kondycję fizyczną i zdrowie, ale także przyczynia się do kształtowania charakteru. Jednak aby aktywność fizyczna przynosiła pozytywne skutki, powinna być odpowiednio realizowana przez placówki i zatrudnioną tam kadrę.

\section{Podsumowanie i wnioski}

Pojęciem resocjalizacji w polskiej literaturze posługiwało się i nadal posługuje wielu autorów. Jako wiodących należy wskazać: Czesława Czapowa, Stanisława Jedlewskiego, Stanisława Górskiego, Lesława Pytkę, Kazimierza Pospiszyla, Bronisława Urbana, Marka Konopczyńskiego, Irenę Pospiszyl22. W niektórych przypadkach rozumienie resocjalizacji jest zgoła odmienne. Przyjmując stanowisko za Marianem Kalinowskim, resocjalizację należy traktować jako cel, proces i efekt ${ }^{23}$. Pierwszy element występuje wówczas, gdy zachowanie jednostki świadczy o tym, że powinna zostać ona poddana procesowi resocjalizacji. Drugi ma miejsce wtedy, gdy za pomocą istniejących metod zostało podjęte oddziaływanie poprawcze i w jego wyniku dokonują się pożądane zmiany. Z kolei o efekcie mówimy wówczas, kiedy w rezultacie tego oddziaływania uzyskano efekt poprawczy.

$\mathrm{W}$ podjętych badaniach i rozważaniach skupiono się na elemencie drugim. W tym kontekście proces resocjalizacji jest prowadzony poprzez sport. Dlatego być może warto na grunt polskiej myśli pedagogiki resocjalizacyjnej zaadaptować wychowawcze wartości kultury fizycznej, jakie opisała Komisja Europejska w Białej księdze. We wskazanym dokumencie zawarto szereg zaleceń, by sport

20 Mariusz Torosz, Monika Storko, „Profil i struktura osobowości, agresji i motywacji sportowej reprezentantek Polski w piłce nożnej”, Sport Wyczynowy 7-8 (2002), 21-33.

${ }^{21}$ Anetta Jaworska, „Aktywność fizyczna w zakładach karnych a podstawowe wymiary osobowości mężczyzn odbywających karę pozbawienia wolności”, Resocjalizacja Polska 9 (2015), 142.

22 Henryk Machel, „Resocjalizacja penitencjarna: istota, dylematy terminologiczne, społeczny sens, kilka uwag teoretycznych i kadrowych", Resocjalizacja Polska 1 (2010), 174-192.

23 Marian Kalinowski, Europejskie systemy resocjalizacji penitencjarnej (Warszawa: WSiP, 1991), 8. 
i wychowanie fizyczne potraktować jako podstawowy element procesu wychowania. Opisane w tamtejszym dokumencie kategorie wartości wydają się być kluczowe również w procesie resocjalizacji:

- poznawcze: uczestnicy zajęć mają mieć szansę zapoznania się z zasadami, przepisami i regułami obowiązującymi w poszczególnych dyscyplinach sportowych, tym samym powinni uzyskać wiedzę z zakresu rozwoju fizycznego i motorycznego;

- estetyczno-artystyczne: zajęcia rekreacyjno-sportowe mają dawać szansę wykształcenia poczucia piękna, rytmu, systematyczności, tempa, dokładności;

- społeczne: drużyna sportowa powinna sprzyjać kształtowaniu umiejętności tworzenia więzi i relacji interpersonalnych;

- moralne: zajęcia rekreacyjno-sportowe powinny rozwijać pożądane cechy, takie jak uczciwość i sprawiedliwość, a największa odpowiedzialność spoczywać ma na wychowawcy/trenerze/instruktorze;

- witalne: aktywność sportowa ma sprzyjać zdrowiu, prawidłowemu rozwojowi fizycznemu i motorycznemu;

- pragmatyczne: systematyczny udział w zajęciach rekreacyjno-sportowych ma przygotowywać do rzetelnej pracy, służyć rozwijaniu talentu, wyrobieniu zaradności;

- materialne: należy wpajać młodym ludziom, że z uprawiania sportu można czerpać korzyści materialne;

- hedonistyczne: prowadzić tak zajęcia rekreacyjno-sportowe, by dawały one pozytywne doznania poprzez zabawę i rozrywkę.

Obierając wymienione założenia, przyjmujemy, że aktywność rekreacyjno-sportowa stanowi narzędzie do internalizacji wartości pożądanych. Proces wychowania, w tym proces resocjalizacji, powinien być wówczas ukierunkowany na wartości nadrzędne, takie jak: demokracja, wolność, zdrowie, tolerancja, pokój czy sprawiedliwość. Wskazane wartości są aksjologicznymi wytycznymi w obszarze kultury fizycznej ${ }^{24}$. Resocjalizacja w kulturze fizycznej skupia się zatem na współdziałaniu rozwoju umysłowego, moralnego i estetycznego.

Powyższe założenia wydają się warte wdrożenia lub mogą stanowić chociażby zaproszenie do szerszej dyskusji i refleksji nad procesem resocjalizacji przez metodę sportu. Tym samym z perspektywy niniejszych rozważań są istotne, gdyż postępowanie badawcze pozwoliło przyjąć hipotezę, że w procesie instytucjonalnej resocjalizacji niedostosowanych społecznie dziewcząt sport jest pożądaną metodą pracy wychowawczej, ponieważ cieszy się dużym zainteresowaniem, umożliwia rozwijanie pasji sportowych, pomaga przyjemnie spędzać czas, redukuje stres. Ponadto zaplecze MOW do organizacji zajęć sportowych i kompetencje

24 Przemysław Król, Resocjalizacja nieletnich środkami kultury fizycznej, http://www.publikacje.edu.pl/publikacje.php?nr=10974 (dostęp: 3.04.2020). 
kadry pedagogicznej $\mathrm{w}$ opinii niedostosowanych społecznie dziewcząt były wystarczające.

Choć otrzymane wyniki badań skłaniają ku propagowaniu sportu jako metody $w$ procesie instytucjonalnej resocjalizacji nieletnich, to zebrany materiał nie pretenduje do miana uogólnienia. W prezentowanych badaniach wzięła udział niezbyt liczna próba badawcza. Ankietyzacji została poddana również tylko jedna z płci. Wybrany do badań ośrodek wychowawczy nie jest także jedyną placówką dla nieletnich przewidzianą $\mathrm{w}$ polskim systemie resocjalizacji instytucjonalnej. Wśród innych należy wymienić młodzieżowe ośrodki socjoterapii (MOS), schroniska dla nieletnich (SdN), zakłady poprawcze (ZP). We wskazanych placówkach wykorzystywanie zajęć sportowych $\mathrm{w}$ procesie resocjalizacji nieletnich wydaje się słuszne. Wskazują na to nie tylko niniejsze wyniki, ale też te, które uzyskali inni badacze. Należy zaznaczyć, że przypisywanie samym zajęciom sportowym szczególnych zasług wychowawczych nie znajduje pełnego uzasadnienia. W wielu placówkach prócz aktywności fizycznej są ponadto wykorzystywane inne metody. Pozytywne zatem rezultaty pracy wychowawczej rozpatrywać należy jako sumę poprawnie skompensowanych zajęć sportowych z innymi powszechnie stosowanymi metodami w procesie resocjalizacji.

Streszczenie: Celem podjętych $w$ artykule rozważań jest ukazanie sportu jako metody resocjalizacji nieletnich dziewcząt $\mathrm{w}$ środowisku instytucjonalnym. $\mathrm{Z}$ celem tym koresponduje problem badawczy zawarty w pytaniu dopełnienia: czy, a jeżeli tak, to w jakim stopniu i w jaki sposób sport może stanowić pożądaną metodę pracy wychowawczej w procesie instytucjonalnej resocjalizacji niedostosowanych społecznie dziewcząt? W badaniach wzięło udział 71 nieletnich płci żeńskiej przebywających w młodzieżowym ośrodku wychowawczym. Postępowanie badawcze zrealizowano przy pomocy metody sondażu diagnostycznego z uwzględnieniem techniki ankiety i jej autorskim kwestionariuszem pełniącym funkcję narzędzia badawczego. Na podstawie badań została przyjęta hipoteza, że w procesie instytucjonalnej resocjalizacji niedostosowanych społecznie dziewcząt sport jest pożądaną metodą pracy wychowawczej, ponieważ cieszy się dużym zainteresowaniem, umożliwia rozwijanie pasji sportowych, pomaga przyjemnie spędzać czas, redukuje stres. Ponadto zaplecze młodzieżowego ośrodka wychowawczego do organizacji zajęć sportowych i kompetencje kadry pedagogicznej w opinii niedostosowanych społecznie dziewcząt są wystarczające.

Słowa kluczowe: sport, resocjalizacja nieletnich, metodyka resocjalizacji, młodzież niedostosowana społecznie, trudna młodzież

\section{Bibliografia}

Biała księga. Biała księga na temat sportu. Bruksela: Komisja Wspólnot Europejskich, 2007.

Bogg, Tom, Roberts, Beniamin William. „Conscientiousness and Health-Related Behaviors: A Meta-Analysis of the Leading Behavioral Contributors to Morality”. Psychological Bulletin 130 (2004), 887-919. 
Czapów, Czesław, Jedlewski, Stanisław. Pedagogika resocjalizacyjna. Warszawa: PWN, 1971.

Eysenck, Hans Jürgen, Nias, Don Karl Bean, Cox, Dan Norman. „Advances in Behaviour Research \& Therapy". Sport and Personality 4 (1982), 170-199.

Gallagher, Patrick, Yancy, William, Denisen, Jaap, Kühnel, Anja, Voils, Corrine. „Correlates of Daily Leisure-Time Physical Activity in a Community Sample: Narrow Personality Traits and Practical Barriers". Health Psychology 1 (6) (2012).

Górski, Stanisław. Metodyka resocjalizacji. Warszawa: Instytut Wydawniczy Związków Zawodowych, 1985.

Jagielska, Monika. Sport i rekreacja w procesie resocjalizacji nieletnich, http://www.mow.powiat.koszalin.pl/przyklady/publikacje/MJ.pdf (dostęp: 8.02.2020).

Jaworska, Anetta. „Aktywność fizyczna w zakładach karnych a podstawowe wymiary osobowości mężczyzn odbywających karę pozbawienia wolności”. Resocjalizacja Polska 9 (2015), 137-157.

Kajtna, Tanja, Tusak, Matej, Barić, Renata, Burnik, Stojan. „Personality in High-Risk Sports Athletes". Kinesiology 36 (1) (2004), 24-34.

Kalinowski, Marian. Europejskie systemy resocjalizacji penitencjarnej. Warszawa: WSiP, 1991.

Karpuszenko, Elena, Marzec, Arkadiusz. Sport w resocjalizacji nieletnich. Częstochowa: Akademia im. Jana Długosza, 2008.

Konopczyński, Marek. Metody twórczej resocjalizacji. Warszawa: PWN, 2008.

Król, Przemysław. Resocjalizacja nieletnich środkami kultury fizycznej, http://www.publikacje.edu. pl/publikacje.php?nr=10974 (dostęp: 3.04.2020).

Machel, Henryk. „Resocjalizacja penitencjarna: istota, dylematy terminologiczne, społeczny sens, kilka uwag teoretycznych i kadrowych". Resocjalizacja Polska 1 (2010), 174-192.

Pilch, Tadeusz, Bauman, Teresa. Zasady badań pedagogicznych. Strategie ilościowe i jakościowe. Warszawa: Wydawnictwo Akademickie „Żak”, 2001.

Poklek, Robert. „Wpływ aktywności fizycznej na poziom agresji młodocianych przestępców”. Zeszyty Naukowe Wyższej Szkoły Pedagogiki i Administracji w Poznaniu 2 (2006), 234-243.

Rhodes, Ryan, Smith, Neil. „Personality Correlates of Phisical Activity: A Review and Meta-Analysis”. British Journal of Sports Medicine 40 (2006), 958-965.

Robacha, Jadwiga, Kostrzyńska, Małgorzata. „Postawy młodzieży niedostosowanej społecznie wobec aktywności fizycznej”. W: Zapobieganie wykluczeniu z systemu edukacji dzieci i młodzieży nieprzystosowanej społecznie. Perspektywa pedagogiczna, red. Joanna Elżbieta Kowalska. Łódź: Wydawnictwo Uniwersytetu Łódzkiego, 2014, 201-217.

Sas-Nowosielski, Krzysztof. „Wychowanie przez sport - między nadzieją a zwątpieniem (II)”. Sport Wyczynowy 7-8 (2004), 64-79.

Tkaczyk, Michał, Paczyńska-Jędrycka, Małgorzata. Pedagogika kultury fizycznej w pracy resocjalizacyjnej poznańskiego zakładu poprawczego, http://www.poznan.zp.gov.pl/wp-content/uploads/2018/05/Pedago-gika-kultury-fizycznej.pdf (dostęp: 10.02.2020).

Torosz, Mariusz, Storko, Monika. „Profil i struktura osobowości, agresji i motywacji sportowej reprezentantek Polski w piłce nożnej”. Sport Wyczynowy 7-8 (2002), 21-33.

Ustawa z dnia 26 października 1982 r. o postępowaniu w sprawach nieletnich, Dz.U. 1982, nr 35, poz. 228 ze zm.

Zimna-Walendzik, Ewa, Szatko, Franciszek. „Udział sportu w modyfikacji stylu życia młodzieży resocjalizowanej”. Problemy Higieny i Epidemiologii 93 (1) (2012), 67-70. 